\title{
Metabotropic Glutamate Receptor 7
}

National Cancer Institute

\section{Source}

National Cancer Institute. Metabotropic Glutamate Receptor 7. NCI Thesaurus. Code C114537.

Metabotropic glutamate receptor 7 (915 aa, $102 \mathrm{kDa}$ ) is encoded by the human GRM7 gene. This protein is involved in ligand-mediated signaling. 